\title{
Serum tumor necrosis factor alpha increased during remission with Etanercept
}

\author{
Mihaela Spirchez ${ }^{1 *}$, Gabriel Samasca ${ }^{2}$ Claudia Bolba ${ }^{1}$, Nicolae Miu ${ }^{1}$ \\ From 18th Pediatric Rheumatology European Society (PReS) Congress \\ Bruges, Belgium. 14-18 September 2011
}

\section{Background}

Existing medical evidence regarding cytokine profile in both plasma and synovial fluid support significant changes in Juvenile Idiopathic Arthritis (JIA) patients.

\section{Aim}

To evaluate the possible role of TNF- $\alpha$ in monitoring disease activity in JIA.

\section{Methods}

In a 2-year prospective study, TNF- $\alpha$ levels were measured using ELISA in 63 serum samples and 4 synovial fluid (SF) samples, for 40 JIA patients. The control population consisted of 18 healthy children. The data were correlated with disease activity and severity (quantified with JADAS27 score) and also with several biomarkers of inflammation.

\section{Results}

TNF- $\alpha$ was measurable in 39 serum samples and in all SF samples. Only $19 \%$ of serum samples had greater TNF- $\alpha$ levels than controls. The most elevated levels of serum TNF- $\alpha$ were found in patients during clinical remission with Etanercept. In one patient with seropositive polyarticular disease, Etanercept administration for 6 months resulted in important elevation of serum TNF- $\alpha$, regardless of clinical improvement. SF levels were significantly higher than simultaneously serum levels $(\mathrm{p}=0.02)$, with no significant differences among oligoarticular and polyarticular forms of JIA. We found no correlation of serum TNF- $\alpha$ values with disease activity and severity. In our patients the circulating TNF- $\alpha$ values were significantly correlated only with

\footnotetext{
* Correspondence: mihaelaspirchez@gmail.com

'Department of Pediatrics, 2nd Pediatric Clinic, "Iuliu Hațieganu” University of Medicine and Pharmacy Cluj-Napoca, Romania

Full list of author information is available at the end of the article
}

hemoglobin levels $(\mathrm{r}=-0.30 ; \mathrm{p}=0.04)$ in the oligoarticular group and with serum Immunoglobulin $\mathrm{G}(\mathrm{r}=0.70$; $\mathrm{p}<0.01)$ in the systemic group.

\section{Conclusions}

We found no correlation of serum TNF- $\alpha$ values with disease activity and severity. Upon treatment with Etanercept, although many JIA patients reached remission on medication, they developed increased circulating TNF- $\alpha$ levels.

\section{Author details}

'Department of Pediatrics, 2nd Pediatric Clinic, "Iuliu Hațieganu” University of Medicine and Pharmacy Cluj-Napoca, Romania. ${ }^{2}$ Department of Immunology, "Iuliu Hațieganu" University of Medicine and Pharmacy ClujNapoca, Romania.

Published: 14 September 2011

doi:10.1186/1546-0096-9-S1-P108

Cite this article as: Spirchez et al:: Serum tumor necrosis factor alpha increased during remission with Etanercept. Pediatric Rheumatology 2011 9(Suppl 1):P108.

Submit your next manuscript to BioMed Central and take full advantage of:

- Convenient online submission

- Thorough peer review

- No space constraints or color figure charges

- Immediate publication on acceptance

- Inclusion in PubMed, CAS, Scopus and Google Scholar

- Research which is freely available for redistribution

Submit your manuscript at www.biomedcentral.com/submit

\section{() Biomed Central}

